\title{
ОРГАНІЗАЦІЙНО-ПЕДАГОГІЧНІ УМОВИ ВПЛИВУ ПРЕДМЕТНО-МЕТОДИЧНОЇ КОМПЕТЕНТНОСТІ ВЧИТЕЛЯ СУСПІЛЬСТВОЗНАВЧИХ ДИСЦИПЛІН НА ФОРМУВАННЯ СУСПІЛЬСТВОЗНАВЧИХ КОМПЕТЕНЦІЙ УЧНІВ
}

Старєва А. М. Організаційно-педагогічні умови впливу предметно-методичної компетентності вчителя суспільствознавчих дисциплін на формування суспільствознавчих компетенцій учнів.

У статті аналізується компетентнісний підхід до процесу навчання за новими державними освітніми стандартами (на прикладі освітньої галузі «Суспільствознавство»), визначаються організаційно-педагогічні умови впливу предметно-методичної компетентності вчителя суспільствознавчих дисциплін на формування суспільствознавчих компетенцій учнів.

Ключові слова: компетентнісний підхід, суспільствознавча компетентність учня, предметна компетенція учня, предметно-методична компетентність учителя суспільствознавчих дисциплін.

Старева А. М. Организационно-педагогические условия влияния предметно-методической компетентности учителя обществоведческих дисциплин на формирование обществоведческих компетенций учащихся.

В статье анализируется компетентностный подход к процессу обучения по новыми государственным образовательным стандартам (на примере образовательной области «Обществознание»), определяются организационно-педагогические условия влияния предметнометодической компетентности учителя обществоведческих дисциплин на формирование обществоведческих компетенций учащихся.

Ключевые слова: компетентностный подход, обществоведческая компетентность ученика, предметная компетенция ученика, предметно-методическая компетентность учителя обществоведческих дисциплин.

Staryeva A. M. Organizational and pedagogical conditions of influence of the objective and methods competence of teachers of Social Science disciplines on the formation of social science skills of students.

The author analyzes the competence-based approach to the learning process according to new state educational standards (on the example of educational field «Social Science»), defines organizational and pedagogical conditions of influence of the objective and methods competence of teachers of Social Science disciplines on the formation of social science skills of students.

Key words: competence approach, social science student competence, subject student competence, subject and methodological competence of teachers of Social Science disciplines.

У вітчизняній педагогіці нині активно обговорюється проблема формування компетентної людини, компетентнісного підходу до процесу навчання [10]. Стратегія реформування освіти на основі нових державних освітніх стандартів [3; 4] передбачає, що в основу змісту загальної освіти мають бути покладені учнівські компетентності.

Змістове наповнення суспільствознавчих дисциплін, формування відповідних учнівських компетенції, як і компетентнісний підхід у шкільній суспільствознавчій освіті, стали предметом дослідження у працях Т. Бакки, К. Баханова, А. Булди, Н. Гупана, Р. Свтушенко, Т. Ладиченко, О. Пометун, Т. Ремех, І. Смагіна, О. Турянської, Г. Фреймана та багатьох інших.

Метою статті є аналіз компетентнісного підходу до процесу навчання за новими державними освітніми стандартами (на прикладі освітньої галузі «Суспільствознавство») як умови успішної підготовки випускника середньої школи та обгрунтування впливу предметно-методичної компетентності вчителя суспільствознавчих дисциплін на формування суспільствознавчих компетенцій учнів. 
Згідно з визначенням Міжнародного департаменту стандартів для навчання, досягнення та освіти (International Board of Standards for Training, Performans and Instruction) поняття компетентності визначається як спроможність кваліфіковано здійснювати діяльність, виконувати завдання або роботу [16]. Департамент пропонує виокремити з цього поняття такі індикатори, як набуті знання, вміння, навички та навчальні досягнення. Експерти програми «DESECO» визначають поняття компетентності (competency) як здатність успішно задовольняти індивідуальні та соціальні потреби і виконувати поставлені завдання [15].

У більшості зарубіжних досліджень останніх років (Cl. Beelishe, M. Linard, B. Rey, L. Turkal, M. Joras i iн.), поняття «компетенція» витлумачується як здатність чи готовність мобілізувати всі ресурси (організовані в систему знання та вміння, навички, здібності і психологічні якості), необхідні для виконання завдання на високому рівні, адекватні конкретній ситуації, тобто відповідно до цілей і умов перебігу процесу [14].

Російські дослідники виокремлюють три підходи до визначення цих понять:

-компетенції і компетентності - терміни тотожні в силу практико-орієнтованості освіти (Л. Болотов, В. Сериков, В. Ледньов, Н. Нікандров, М. Рижаков) [1; 9] або синонімічні (Т. Гудкова, С. Дружилова, Е. Зеєр та ін.) [2; 5; 6];

-компетенції - складники компетентності (К. Махмурян, І. Перестороніна та ін.) [10; 12];

-компетентність - здатність до діяльності, а компетенція - коло повноважень певної особи (С. Шишов, В. Кальней та ін.) [13].

На думку Н. Бібік, поняття «компетенція» $\epsilon$ соціально закріпленим освітнім результатом, а «компетентність» - оціночна категорія, здатність людини успішно виконувати свої повноваження [7].

Під компетентністю людини, О. Пометун розуміє спеціально структуровану (організовану) сукупність знань, умінь, навичок і ставлень, що іх набувають у процесі навчання, які дозволяють людині визначати і розв'язувати проблеми, характерні для певної сфери діяльності. [7].

Отже, у визначенні поняття «компетентність» наявні погляди, що свідчить про діалектику дефініції в контексті нових наукових досліджень із проблем компетентнісного підходу в освіті.

Навіть у нових державних стандартах немає чіткої дефініції: «компетентність» тлумачиться в більшості як «здатність» [3, с. 2-3; 4, с. 5-7], інколи - як «особистісне утворення» $[4$, с. 5] чи «досвід» [4, с. 3].

Аналогічно термін «компетенція» подається в обох освітніх стандартах як «суспільно визнаний рівень», а «предметна компетенція» як «сукупність знань, умінь та характерних рис» $[3$, с. $4 ; 4$, с. 3$]$.

Здійснений аналіз різних підходів до визначення компетенцій та компетентностей дозволив зробити висновки, що слугують для нас підгрунтям формування власного тлумачення природи цього феномену: по-перше, дослідники відзначають діяльнісну сутність компетентності, підкреслюючи, що на відміну від знаннєвої характеристики («що»), тут акцентується на способі й характері дії («як»); по-друге, більшість науковців відзначають ціннісну (для суспільства, держави, людства) основу компетентності; по$m p e m \epsilon$, виокремлюють особистісну, зокрема мотиваційну характеристику компетентності, інтерес, ставлення.

Іншими словами, компетентна людина повинна: знати що і як робити (індикаторами постають знання), вміти робити, виконувати (індикатори - вміння), бажати це робити (індикатори - мотиви, інтереси), оцінювати, порівнювати, цінити зроблене (індикатори навички, иіннісний досвід).

Два державні стандарти, що регулюють освітній процес сучасної школи I-III ступенів, розподіляються на сім освітніх галузей, із яких - шість розпочинаються з 1 класу і лише освітня галузь «Суспільствознавство» - iз 3 класу. Дитина із входженням до школи, вступає 
до нової спільноти, де вона має себе самоідентифікувати, комунікаційно налагодити стосунки в учнівському колективі, школі на різних рівнях (з однолітками, із старшокласниками, з учителями, адміністрацією, технічними працівниками, психологом, медичним персоналом тощо), сприйняти й дотримуватися правил і норм шкільної взаємодії, брати участь в організації освітнього процесу, громадського життя класу, школи, села (міста) тощо. Формування найважливіших громадянських та суспільних компетенцій учнів «відкладається» на два роки, що може призвести до усвідомлення їх меншовартості. I хоча освітні галузі «Мистецтво» та «Технології» у старшій школі також не представлені повноцінно в інваріантному складнику базового навчального плану, все ж віднесення їх до вибірково-обов'язкових дисциплін нормативно закріплює їх права в навчальному процесі школи [3].

У Державному стандарті початкової загальної освіти освітня галузь «Суспільствознавство» висуває перед учителями як головну мету формування соціальної $\mathrm{i}$ громадянської компетентностей, що характеризуються як ключові, мають «міждисциплінарний характер та інтегруються за допомогою всіх освітніх галузей i спрямовуються на соціалізацію особистості, набуття громадянських навичок співжиття i співпраці в суспільстві, дотримання соціальних норм» [4, с. 12].

Водночас, на наш погляд, дещо запізно в Державному стандарті базової та повної загальної середньої освіти ставляться завдання «розвитку інтелекту дитини, ії критичного мислення, визначення нею власної ідентичності як особистості, громадянина, члена родини, етнічної, релігійної, регіональної та локальної спільноти» [3, с. 10].

Із входженням до нової спільноти має проходити процес самоідентифікації дитини: «Хто я?», «моє місце в колективі?», «моя соціальна роль?», «мої завдання?», «правила і норми, яких я маю дотримуватися?» тощо. То ж робити це в основній школі чи навіть в 34 класах запізно. На наш погляд, формування соціальної і громадянської компетентностей учнів у школі має розпочинатися з першого класу. Відсутність у базовому плані з 1 класу освітньої галузі «Суспільствознавство» зумовлює перенесення завдань у позаурочний час та необхідність методичного розроблення вчителем організаційних, виховних заходів суспільствознавчої спрямованості.

Понятійна невизначеність наявна й у визначенні головних термінів освітньої галузі: за основу формування предметної складової беруться соціальна, громадянська (Державний стандарт початкової школи) та інші ключові й галузеві компетентності (Державний стандарт базової і повної загальноосвітньої школи). I хоча в загальній частині державного стандарту надається визначення терміна «предметна (галузева) компетентність - набутий учнями у процесі навчання досвід специфічної для певного предмета діяльності, пов'язаної із засвоєнням, розумінням і застосуванням нових знань» [3], усе ж визначення головного терміна - «суспільствознавча компетентність» - у стандартах відсутнє. Це, а також вживання дефініцій «соціальна» i «суспільна» в обох освітніх стандартах ускладнює вчителюсуспільствознавцю формулювання мети уроку.

Аналіз термінів, розуміння узгодженості завдань і очікуваних результатів освітньої галузі «Суспільствознавство» дозволяе нам сформулювати робочі поняття: суспільствознавча компетентність учня як набута ним у процесі навчання інтегрована здатність до специфічної діяльності (суспільної, громадянської, правової, економічної), що цілісно реалізується на практиці та складається зі знань, умінь, досвіду, цінностей і ставлення до людини і суспільства та предметна(історична, правова, економічна) компетенція учня як сукупність його знань, умінь та характерних якостей у межах змісту конкретного предмета (історія, правознавство, економіка), необхідних для виконання ними певних дій задля розв'язання навчальних проблем, задач, ситуацій.

Систему компетентностей в освіті складають: ключовi, загальногалузеві - набуваються учнем упродовж засвоєння змісту певної освітньої галузі у середній школі, та предметні компетентності- набуваються учнем упродовж вивчення того чи того предмета у середній школі. 
«Суспільствознавство» - освітня галузь, ядром якої є сукупність педагогічно відібраних наукових знань про людину і суспільство. Засадничими для шкільної суспільствознавчої освіти $\epsilon$ науки, що вивчають суспільство: економіка, соціологія, політологія, культурологія, юридичні науки, а також філософія. Поряд 3 науковими знаннями в суспільствознавчих курсах представлені соціальні норми, система гуманістичних i демократичних цінностей, способи пізнавальної і практичної діяльності, а також інші елементи моральної, економічної, політичної, правової культури, культури соціальної поведінки громадян. Суспільствознавчі дисципліни покликані сприяти соціалізації особистості в умовах динамічного світу, саме тому однією із важливих компетентностей, формування якої передбачається в освітній галузі державних стандартів, є «соиіальна компетентність - здатність особистості продуктивно співпрацювати 3 партнерами в групі та команді, виконувати різні ролі та функції в колективі» [4; 3].

Суспільствознавчі дисципліни також зорієнтовані на залучення учнів до цінностей громадянського суспільства, отже, актуалізують формування «громадянської компетентності учня - здатності активно, відповідально та ефективно реалізовувати права та обов'язки задля розвитку демократичного суспільства» [4; 3$]$.

Елементи предметних компетентностей суспільствознавчих дисциплін наскрізно формуються на трьох ступенях шкільного навчання: початковій, базовій, повній школі. Предметні (історичні, правові, економічні) компетентності завдяки предметам (історія, правознавство, економіка) і засобам їх основних змістових ліній (людина в суспільнополітичній сфері, людина в соціальній сфері, людина у правовій сфері, людина в економічній сфері, людина в культурно-духовній сфері) інтегруються в галузеву (суспільствознавчу) компетентність. Тому під час проектування процесу формування суспільствознавчої компетентності учнів учителю необхідно:

1. Проаналізувати типи учнівських компетентностей за державними стандартами в загальній ієрархії (ключова, галузева, предметна компетентність).

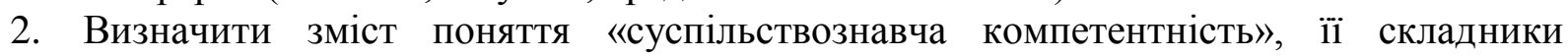
(предметні компетентності).

3. Визначити зміст предметної (історичної, правової, економічної) компетентності за роками навчання.

4. Встановити, які знання, вміння, навички та способи діяльності формуються відповідною темою курсу (історія, правознавство, економіка).

5. Сформувати знаннєвий, діяльнісний, соціально-практичний, аксіологічний складники предметної компетентності як процесуальний фундамент для інтегрування в суспільствознавчу компетентність.

Оцінювання суспільствознавчих компетенцій учнів має охоплювати такі компоненти:

1) знання та вміння, виявлені в оволодінні основними поняттями та процедурами із суспільствознавчих дисциплін, конкретної теми;

2) ситуативну поведінку, адекватну певній ситуації, вміння виконувати конкретні дії, виявляти свою світоглядну позицію;

3) осмислення і моральну оцінку фактів, подій, явищ, процесів, репрезентацію себе як можливого учасника ситуацій (рефлексивний складник пізнавальної діяльності).

Головною умовою формування предметних компетенцій учнів $є$ наявність сформованої предметно-методичної компетентності вчителя. Компетентність учителя виявляється в його здатності осмислювати нові концепції предмета, нові педагогічні технології, вибирати програму і підручники із пропонованих варіантів, оцінювати їх з урахуванням специфіки методики предмета, власних можливостей, типу навчального закладу i особливостей учнів. При цьому поведінка вчителя грунтується на його професійній самосвідомості, що визначається рівнем методичного мислення, що, відповідно, потребує постійного розвитку як у процесі самопідготовки, так і під час обговорення на методичних об’єднаннях, курсах підвищення кваліфікації. 
Вирізнення характерологічного змісту дефініції, дозволяє охарактеризувати предметнометодичну компетентність учителя суспільствознавчих дисциплін як складник його професійної здатності здійснювати методичну діяльність, пов'язану із навчанням предметів шкільної освітньої галузі «Суспільствознавство», що є результатом системної, багаторівневої, поетапної підготовки й виражається в ціннісному ставленні до суспільно-політичних дисциплін, наявності фахових і методичних знань, володінні специфічними для дисциплін суспільствознавчого циклу методичними вміннями та навичками, певному (або ж первинному) педагогічному досвіді навчання суспільствознавства, що означає виконання вчителем професійних дій якісно, щодо відповідно до державних стандартів світи i нормативно-регулюючих документів.

Отже, компетентнісна спрямованість змісту навчальних дисциплін, курсів за новими державними освітніми стандартами; урахування у змісті базових предметів і відповідних методиках навчання тенденцій розвитку суспільно-політичних та психолого-педагогічної наук, що забезпечують розвиток необхідних предметно-методичних компетентностей вчителя-суспільствознавця; неперервна й системна навчальна діяльність із фахових та методичних дисциплін педагога в системі його підготовки та підвищення кваліфікації; застосування сучасних освітніх технологій, зорієнтованих на реалізацію компетентнісного підходу в освіті є оптимальними й необхідними організаційно-педагогічними умовами, зорієнтованими на конкретний результат: формування ключових i предметних компетентностей кожного випускника середнього навчального закладу.

\section{Література}

1. Болотов В. А. Компетентностная модель: от идеи к образовательной программе / В. А. Болотова, В. В. Сериков // Педагогика. - 2003. - № 10. - С. 8-14. 2. Гудкова Т. А. Формирование информационной компетентности будущего учителя информатики в процессе обучения в вузе : автореф. дис. ... на соискание ученой степени канд. пед. наук / Гудкова Т. А. ; Забайкал. гос. гуманит.-пед. ун-т им. Н. Г. Чернышевского. - Чита, 2007. - 22 с. : ил. Шифр РНБ: 2007-A/16708. 3. Державний стандарт початкової загальної освіти / Початкова освіта. № 18(594). 2011. 4. Державний стандарт базової і повної загальної середньої освіти - [Електронний ресурс] Режим доступу : http://mon.gov.ua 5. Дружилова С. А. Этапы формирования профессиональной компетентности // Непрерывное образование как условие развития творческой личности: Сб. мат. Фестиваля педагогического творчества, 28-29 августа 2000 г. - Новокузнецк : ИПК, 2001. - С. $32-$ 36. 6. Зеер Э. Ф. Модернизация профессионального образования: компетентностный подход: [учебное пособие] / Э. Ф. Зеер, А. М. Павлова, Э. Э. Сыманюк - Москва : Московский психологосоциальный институт, 2005. - 216 с. 7. Компетентнісний підхід у сучасній освіті: світовий досвід та українські перспективи / за заг. ред. О. В. Овчарук. - К. : К.І.С., 2004. - 112 с. - (Бібліотека 3 освітньої політики). 8. Компетентность и проблемы ее формирования в системе непрерывного образования (школа - вуз - послевузовское образование) / науч. ред. проф. И. А. Зимняя; Материалы XVI научно-методической конференции «Актуальные проблемы качества образования и пути их решения». - М. : Исследовательский центр проблем качества подготовки специалистов, 2006. - 130 с. 9. Леднев В. С. Государственные образовательные стандарты в системе общего образования:теория и практика / В. С. Леднев, Н. Д. Никандров, М. В. Рыжаков - М., 2002. 10. Махмурян К. С. Методические основы подготовки учителя иностранного языка в системе дополнительного профессионального образования: [монография]. - М. : Университет, 2008. - 405 c. 11. Національна доповідь про стан і перспективи розвитку освіти в Україні (друге видання) / Нац. акад. пед. наук України ; [авт.: В. П. Андрущенко, І. Д. Бех, М. І. Бурда та ін.; редкол.: В. Г. Кремень (голова), В. І. Луговий (заст. голови), В. М. Мадзігон (заст. голови), О. Я. Савченко (заст. голови)] ; за заг. ред. В. Г. Кременя. - К. : Пед. думка, 2011. - 304 с. - Бібліогр. : с. 149-167. - (До 20-річчя незалежності України). 12. Пересторонина И. Л. Особенности формирования профессиональной компетентности будущего учителя при изучении второго иностранного языка // Научное исследование и российское образование: идеи и ценности 21 века. Материалы 6-й междисциплинарной научно-практической конференции аспирантов и соискателей (3-4 апреля 2003 года) / Сост. Н. В. Фанькина. - М. : АПК и ПРО, 2003. - С. 177-181. 13. Шишов С. Е. Мониторинг качества образования в школе / С. Е. Шишов, В. А. Кальней. - М. : Российское педагогическое агентство, 1998. - 320 c. 14. Isaeva T. Е. To the nature of Pedagogical Culture: Competence - Based approach to its Structure//Преподаватель высшей школы в XXI веке. Труды 
Международной научно-практической интерконференции. - Ростов-на-Дону, 2003. 15. Definition and Selection of Competencies. Theoretical and Conceptual Foundations (DESECO). Strategy Paper on Key Competencies. An Overarching Frame of Reference for an Assessment and Research Program OECD (Draft). 16. Tuning Educational Structures in Europe/ Line 1. Learning Outcomes/Competencies Methodology, 2001-2003. Phase 1. http://www. Relint. Deusto. es/Tuning Project/index.htm.

УДК 378.147:159.947.5

3. I. Cmуnак,

старший викладач,

Криворізький педагогічний інститут

ДВНЗ «Криворізький начіональний університет»

\section{АНАЛІЗ НАВЧАЛЬНОЇ МОТИВАЦІЇ ЯК ОСНОВИ НАВЧАЛЬНО-ПІЗНАВАЛЬНОЇ ДІЯЛЬНОСТІ СТУДЕНТІВ}

Ступак 3. І. Аналіз навчальної мотивації як основи навчально-пізнавальної діяльності студентів.

У статті на основі аналізу навчальної мотивації як основи навчально-пізнавальної діяльності студентів здійснено спробу виявити чинники, що впливають на вибір майбутньої спеціальності, а також мотивацію навчальної діяльності студентів.

Ключові слова: мотиви, мотивація, мотиваційна діяльність, потреби, процес навчання.

Ступак 3. И. Анализ учебной мотивации как основы учебно-познавательной деятельности студентов.

В статье на основе анализа учебной мотивации как основы учебно-познавательной деятельности студентов предпринята попытка выявить факторы, влияющие на выбор будущей специальности, а также мотивацию учебной деятельности студентов.

Ключевые слова: мотивы, мотивация, мотивационная деятельность, потребности, процесс обучения.

Stupak Z. I. Analyses of learning motivation as a basis for learning and cognitive activity of students.

On the basis of analysis of learning motivation as a basis for learning and cognitive activity of students attempted to identify factors that influence the choice of future profession, as well as the motivation of learning activities of students.

Key words: motives, motivation, motivational activities, needs, the process of learning.

Навчальна діяльність спрямована на оволодіння узагальненими способами дій у галузі наукових понять. Вона повинна спонукатися адекватними мотивами, що безпосередньо пов'язані 3 iï змістом: мотиви придбання узагальнених способів дій, мотиви самовдосконалення.

Початок XXI століття позначений активним пошуком шляхів реформування освітянської системи України. У вищій школі ця проблема розглядається переважно в аспекті відповідності навчальної діяльності до вимог стандартів освіти, переходу до іiі триступеневої системи (підготовка за рівнями бакалавра, спеціаліста та магістра). Меншою мірою звернено увагу на необхідність переосмислення мети, змісту, форм i методів підготовки фахівців, перегляду психолого-педагогічної парадигми освіти.

Метою статmі є аналіз навчальної мотивації як основи навчально-пізнавальної діяльності студентів, спроба виявлення чинників, що впливають на вибір майбутньої спеціальності, а також на мотивацію навчальної діяльності студентів.

За останні півстоліття у світі розроблено понад 50 мотиваційних теорій, за кожною 3 яких - сотні й тисячі досліджень.

Теоретичною основою нашого дослідження $є$ ідеї таких науковців, як: Л. Божовича, I. Дмитрієва, А. Дусавицького, А. Занкова, Б. Ельконіна, Л. Копець, К. Костючок, В. Лісовського, А. Матіс, Д. Ніколенко, М. Орлів, Л. Рубінштейна, Х. Хекхаузена, I. Якобсона, та ін.). Із-поміж дослідників передовсім варто зупинитися на працях із питань 